Original Article Received/Accepted Dates

05.11.2021/21.12.2021

DOI: $10.52096 /$ jsrbs.7.14.17
Sosyal Araştırmalar ve Davranış Bilimleri Dergisi

ISSN:2149-178X

Volume: 7 Issue: 14 Year: 2021

\title{
Turistik Ürün Çeşitlendirmesi Kapsamında Ekoturizme Yönelik Projelerin Değerlendirilmesi
}

Dr. Öğr. Üyesi Zişan KORKMAZ ÖZCAN

Süleyman Demirel Üniversitesi

İktisadi ve İdari Bilimler Fakültesi

ORCID: 0000-0002-5842-8638

zisankorkmaz@sdu.edu.tr

\author{
Yüksek Lisans Öğrencisi Hatice ARMAN \\ Süleyman Demirel Üniversitesi \\ İktisadi ve İdari Bilimler Fakültesi \\ ORCID: 0000-0002-1273-8411 \\ haticearman20@gmail.com
}

\section{Özet}

Tüm dünyada her geçen gün popülerliği artmakta olan ekoturizm ile birlikte insanların doğal çevrede yaşama verdikleri önem günden güne artmaktadır. Kitle turizminin de etkisiyle ortaya çıkan çevre kirliliği, doğal yaşam alanların bozulması tüm dünyayı etkilemekte ve ekoturizme zarar vermektedir. Ekoturizm kavramı; yeşil turizm, sorumlu turizm, kırsal turizm, doğa turizmi, macera turizmi, bisiklet turizmi gibi birçok turizm faaliyetleri içerisinde yer almasıyla önemli bir potansiyele sahiptir. Ekoturizm alanında yapılan çalışmaların kültürel ve doğal yapısı bozulmamış destinasyonlar üzerine yoğunlaşılması, turizme etkin bir şekilde sunulması açısından önemlidir. Bu çalışmanın amacı dünyada ekonomik, çevresel ve sosyo-kültürel getiriye sahip olan ekoturizmin Türkiye açısından değerlendirilmesinin yapılmasıdır. Bu çalışmada alanda yapılmış projelerin analizine yer verilmiştir. Araştırmada veri toplamak üzere doküman inceleme yöntemi kullanılarak bibliyometrik analize başvurulmuş, bu amaçla yerel, ulusal ve uluslararası basılı ve elektronik kaynaklar taranmıştır. $\mathrm{Bu}$ doğrultuda 1997-2021 yılları arasındaki yayımlanan projelerin bibliyometrik analizi yapılmaktadır. Yayımlanan çalışmalar YÖK Akademik, Google Scholor veri tabanından "ekoturizm”, "eko turizm", "eko-turizm" kavramları altında erişim sağlanmıştır. Sonuç olarak Türkiye'nin ciddi ekoturizm 
potansiyeline sahip olduğu ve yapılan faaliyetlerin planlı olarak yürütüldüğünde ekoturizm potansiyelinin arttıracağına yer verilmiştir.

Anahtar Kelimeler: Ekoturizm, Sürdürebilir Turizm Projeleri, Turistik Ürün Çeşitlendirme, Bibliyometrik Analiz

\title{
Evaluation of Ecotourism Projects within The Scope of Tourism Product Diversification
}

\begin{abstract}
It is observed that the importance of people to life in the natural environment is increasing day by day with ecotourism, which is increasing in popularity all over the world day by day. Environmental pollution caused by mass tourism, deterioration of natural habitats affects the whole world and damages ecotourism. The concept of ecotourism has an important potential because it is included in many tourism activities such as green tourism, responsible tourism, rural tourism, nature tourism, adventure tourism, bicycle tourism. It is important for the studies in the fields of ecotourism to focus on destinations with intact cultural and natural structure in terms of presenting them effectively to tourism. The aim of this study is to evaluate ecotourism, which has economic, environmental and socio-cultural benefits in the world, in terms of Turkey, and to analyze the projects made in this field. In order to collect data in the research, bibliometric analysis was used by using document analysis method and for this purpose, local, national and international printed and electronic resources were scanned. Bibliometric analysis of published projects between 1997-2021. The published studies were accessed from YÖK Akademik, Google Scholar database under the concepts of "ecotourism", "eco-tourism", "eco-tourism". As a result, it is stated that Turkey has a serious ecotourism potential and if the activities are carried out in a planned manner, the ecotourism potential will increase.
\end{abstract}

Keywords: Ecotourism, Sustainable Tourism Projects, Touristic Product Diversification, Bibliometric Analysis

\section{Giriş}

Turizm, ülkeler arasında rekabetin ön planda olduğu bir sektör haline gelmiştir. Uluslararası alanda rekabetin önüne geçmek amacıyla turistik ürün çeşitliliğine başvurularak turistler için alternatif seçenekler oluşturulmuştur (Güzel, 2010: 87). Bu alternatif seçenekler ile turizm sektöründe meydana gelecek büyümeler, ülke ekonomisini olumlu etkilemekte ve döviz girdisi sağlamaktadır. Günümüzde turizm eğitim seviyesinin yükselmesi, çevre ve doğaya ilgilerinin 
artması, doğa temelli aktivitelerin tercih edilmesiyle turizm pazarında sağlanacak önemli bir potansiyeli beraberinde getirmiştir (Kasalak, 2014: 1).

Ekoturizm türleri de alternatif seçenekte en önemli kısmı oluşturmaktadır. Doğal çevre kaynaklarının korunması ve kullanılması amacıyla sürdürebilirliğini sağlamak amacıyla hedeflenen bir turizm türüdür. Ülkemizin sahip olduğu doğal, tarihi, kültürel kaynakların zenginliği ekoturizm açısından avantajlı kılmaktır (Tutcu, 2021: 5). Ülkemizde bu alanlar adına projeler ile destek vermekte ve ekoturizm merkezlerinde çalışmalar yürütmektedir.

$\mathrm{Bu}$ çalışmanın amacı dünyada ekonomik, çevresel ve sosyokültürel getiriye sahip olan ekoturizmin Türkiye açısından değerlendirilmesinin yapılarak bu alanda yapılmış projeler analiz edilmektedir. Böylece ekoturizmin önemi ortaya koyulmakta, yapılan projeler çevresel, sosyo-kültürel ve ekonomik etkiler açısından gruplandırılmaktadır. Yapılmış projeler doğrultusunda yürütülen çalışmaların Türkiye'yi olumlu etkilediği ve bu faaliyetlerin planlı artırılması gerektiği üzerinde durulmuştur.

Araştırmada veri toplamak üzere doküman inceleme yöntemi kullanılarak bibliyometrik analize başvurulmuş ve bu amaçla yerel, ulusal ve uluslararası basılı ve elektronik kaynaklar taranmıştır. 1989 ve 2017 yılları arasını kapsayan projelere erişim sağlanılmıştır. Yılları tespit edilemeyen proje çalışmaları ise " $x$ " ifadesi verilerek çalışmaya dahil edilmiştir. Çalışmada öncelikle turistik ürün çeşitlendirilmesi, ekoturizm, ekoturist, seyahat ve motivasyonları ile ilgili alan yazısına yer verilmektedir. İkinci bölümde yöntem hakkında bilgi verilmektedir. Bulgular kısmında da projelerden elde edilen veriler doğrultusunda tablolaştırma ve yorumlama yapılmaktadır. Sonuç bölümünde ise, araştırmanın genel sonuçları ortaya koyulmaktadır.

\section{Kavramsal Analiz}

\subsection{Turistik Ürün Çeşitlendirilmesi}

Turistik ürün; bireyin seyahat konaklamalarından kaynaklanan ihtiyaçların karşılanmasıyla oluşan mal, hizmetin karışımı ile oluşan bir pakettir (Demir ve Demir, 2004: 94; Akgöz, Göral ve Tengilimoğlu, 2016: 398). Diğer taraftan turistik ürün, turistin seyahati esnasınca yararlandığı konaklama, yiyecek, içecek, ulaşım, rehberlik hizmeti, eğlence gibi birçok hizmetin bir araya gelmesiyle oluşmaktadır (Tekin, 2014: 2). 
Turistik ürünün çeşitlendirilmesi, ürünün birçok aşamadan değerlendirilmesidir (Buluç, 1997: 142). Bu çeşitliliğin turizmde yapılmış çalışmaların oluşturduğu olumlu etkiler doğrultusunda, ürünlerin tek çeşitlilikten çok çeşitliliğe yer verilerek turizm pazarına sunulduğunda önemli bir rekabeti oluşturmaktadır (Kozak vd., 2003). Ülkelerin sahip olduğu çevresel avantajların tamamlayıcı hizmetler doğrultusunda farklılığa bağlı olarak değişmektedir. Ülkelerin sahip olduğu turistik merkezler birden fazla kaynağa sahip olabilmektedir (Demir ve Demir, 2004: 95, 2004; Güzel, 2010: 89).

\subsection{Ekoturizm}

Ekoturizm faaliyetleri ekolojik kaynaklara zarar verilmemesi amacıyla oluşturulmuş uygulamaları içermektedir (Turpçu ve Çelikkanat Paslı, 2019: 413). Bireylerin doğal alanlarda bulunarak gerçekleştirebileceği seyahatlerin, ekosisteme olumlu olabilecek şekilde oluşturulan seyahatleri kapsamaktadır (Butler ve Boyd, 1996:386). 1983 yılında Meksikalı çevre uzmanı Hector Cabellos-Lascurain'e göre ekoturizm “doğal ve kültürel değerlerin korunmasına teşvik etmesi amacıyla, kişi sayısının az olduğu ve çevreye duyarlı turizm algısını benimseyen bireyler ile bozulmamış doğal alanlara yapılan seyahatler” olarak tanımlanmıştır (Scheyvans, 1999: 245).

Turizm sektöründe önemli bir pazar payına sahip olan ekoturizm, sürdürebilirliğini geliştirerek önemini ortaya koymaktadır (Fang ve Cheng, 2012). Literatürde benzer birçok tanımlamalara rastlanılmaktadır. Uluslararası ekoturizm topluluğuna göre (TIES- The International Ecotourism Society); “doğal çevreyi koruyan ve yerel halkın kalkınmasını sağlayan, sorumlu seyahatlerdir" (Ross and Wall 1999: 124). Bu doğrultuda kitle turizmin neden olduğu olumsuzlukları en aza indirmek amacıyla ortaya çıkmıştır.

1990 yılında Juric, ekoturizmi, “doğal manzaralarda bulunan bitki ve hayvanların, bu alanlarda geçmişte ve günümüzde var olan kültürel özelliklerinin incelenmesi, araştırılması gibi nedenlerle diğer alanlara göre tahribat uğramamış veya kirlenmemiş doğal alanlara yapılan seyahatler" olarak açıklamıştır (Juric vd., 2002: 259) Hens'e göre (1994) ekoturizm, doğal ve kültürel alanların korunması ve ekoturistlerin bu alanların korunması ve sürdürebilirliğini sağlamak amacıyla sağlanmış olan programlardır (Polat, 2006: 11).

Ekoturizm, kitlesel turizmin sebep olduğu olumsuzlukları ortadan kaldırmak amaciyla oluşturulmuştur. Ekoturizm, kitlesel turizmin tersine; içersinde bulunduğu doğal alanların, 
sosyo kültürel varlıklarından yararlanırken alanların korunması ve gelenek kuşağa aktarılması amaçlanmıştır (Kızılırmak vd., 2017: 189). Ekoturizm, doğal alanlara ziyaret eden turistlere, o yeri tanıma olanağı sağlarken doğaya karşı olumsuz davranışlarımızı azaltmaya yönelik çalışılmaktadır (Uğurlu ve Akay, 2017: 28). Ekoturizm, sürdürebilir turizm ve alternatif turizmi desteklemektedir.

\subsection{Ekoturist}

Ekoturizm, ekoturist kavramıyla ifade edilen, değerbilme, katılım sağlama ve duyarlı olarak doğal özellikleri koruyan ve bu alanlara ziyaret eden kişilerdir. Kendilerine göre bir turist algısı vardır (Ongun vd., 2017: 51). Benzer şekilde ekoturist; deniz-kum-güneş konseptinden sıkılan, gittikleri yerin kültüreli öğrenmek, doğal zenginliklerini görmek ve yerel yaşamı deneyimlemek isteyen bireylerdir (Kasalak ve Bahtiyar, 2017: 1089).

Topluma fayda sağlayan ekoturistler, doğayı korumayı amaçlayarak oluşturulan faaliyetlerde duyarlı ve sorumluluğu önemsemektedir (Western, 1993: 8). Uluslararası Ekoturizm Topluluğu ekoturist profilleri incelendiğinde; 35-54 yaş arası olup \%52'i erkek, \%48'i kadın spor ve sosyal aktivitelerde bulunan, bulundukları destinasyonlarda 8 ila 14 gün arasında kalan, sürekli yeni yerler görmek isteyen, iş seyahati amaciyla seyahat eden ekoturistlerin "yeşil otel” olmasına dikkat ettikleri belirtilmiştir (Kurtoğlu ve Temiz, 2018: 94). Ekoturistlerin yıllık gelir ortalamaları, eğitimleri açısından daha iyi oldukları ve geleneksel turistlere göre seyahat esnasında öğrenmeye meraklı oldukları anlaşılmaktadır (Nalıç̧ak, 2020: 23).

\subsection{Motivasyonları ve Seyahat Etme Nedenleri}

Ekoturistlerin seyahat etme nedeni, farklı motivasyon faktörlerinden, motivasyon da, farklı bireye özgü gereksinimlerden ortaya çıkmaktadır. Ekoturist motivasyonları ve beklentilerinde, genel turist tipindeki dinlenme, eğlenme ve aile gibi temel motivasyonlardan farklı olarak doğal çevre odaklı olduğu anlaşılmaktadır. Ekoturistlerin motivasyonları; dağlar, kuşlar, ağaçlar ve yabani çiçekler, tropikal ormanlar, ulusal ve bölgesel parklar, benzer ilgi alanına sahip insanlar ile tanışmak, zamanı iyi değerlendirmek, göller ve ırmaklar, manzaranın fotoğrafını çekmek, okyanus kıyıları, kırsal bölgelerdir (Kasalak ve Bahtiyar, 2017: 1090). 
Akay ve Zengin'e göre ekoturizm motivasyonları (2017); “vahşi ve bozulmamış doğa, göller ve nehirler, kırsal alanlar, okyanus kıyıları, basit yaşam biçimleri, tarihi yerleri ziyaret, benzer ilgi alanlardaki insanlarla tanışmak, yeni yaşam biçimleri yaşamak, fiziksel olarak aktif olma, dağlar, milli ya da bölgesel parklar, sınırlı zamanda oldukça çok yeri gezme, kültürel faaliyetler, yerel el sanatları, kendini yeniden keşfetme, tarihi yerler ve parklar, müzeler ve sanat galerileri, maceracı olmak" ekoturizme yönelik motive edici unsurlar olarak belirtilmiştir (Akay ve Zengin, 2017: 116).

\section{Dünyada Ekoturizm}

Ekoturizm, turizmde sürdürülebilirliğin devamlılığını oluşturmak için ortaya çıkmaktadır. 1992 yılı itibariyle uluslararası alanda ekoturizm önem kazanmaya başlamaktadır. Birleşmiş Milletler, ekoturizme yönelik eğilimlerin artması sonucunda 2002 yılını "Ekoturizm Y1lı" olarak ilan etmektedir (Arat ve Çalımlı, 2018: 30). TIES 2000 y1lında turizm pazarında \%7 oranında, ekoturizm alanında ise yılda $\% 20$ oranında artış ile yükselme gösterdiği belirtilmiştir (Honey, 2007: 175).

Dünyada ekoturizrm incelendiğinde; Orta Amerika, Latin Amerika, Yeni Zelanda, Karayip Adaları, Pasifik Adaları, Güney Doğu Afrika, Güney Doğu Asya, Kenya, Antartika, Nepal, Kosta Rika Belize, Ekvator, Tayland, Tanzanya ve Avustralya ekoturizm açısından önemli destinasyonları barındırmaktadır (Tekin, 2014: 42).

Avustralya, endüstrisinin hızlı gelişmesiyle ekoturizm konusunda ön plandadır. Destinasyon açısından güzel örneklere sahiptir. 1983-1993 yıllarında uluslararası turist sayısı incelendiğinde \%12 oranında büyüme göstererek 944.000'den 3.000.000'a artmıştır. Ekoturizm ile 130.000 bireyin istihdam olanağına sahip olarak 10,6 milyar dolar gelir sağlanmıştır(Yılmaz, 2008: 89; Kasalak, 2014: 109) Kenya'da ise her yıl park ve koruma alanlarına 650.000 kişi ziyarette bulunmaktadır. Ekoturistlerin ortalama 350 milyon dolar harcama yapıldı̆̆ Genellikle yaban hayatın ana çekim noktası olduğu ve sadece filin yılda 14.375 dolar hayatı boyunca da 900.000 dolar üzerinde gelir getirmektedir (Kurnaz ve Babür, 2018: 414). Kosta Rika'nın gelen turist sayısı incelendiğinde 1964 yılında 64.000 'den, 1995 yılında 792.000 ile artış göstermiştir. Turizm gelirleri açısından incelendiğinde 1964 yılında 10 milyon dolara sahipken 1995 yılında 661 milyon dolara yükselerek turizm gelirlerini olumlu etkilemiştir (Y1lmaz, 2008: 90; Kasalak, 2014: 105). 


\section{Türkiye'de Ekoturizm}

Ekoturizm kavramı doğrultusunda "soft ecotourism" (yumuşak ekoturizm) ve "hard ecotoursim" (yoğun ekoturizm) olarak belirtildiği gözlemlenmiştir. Yoğun turizm; bireyin doğa ile uzun süre ilişki kurması olarak bahsedilirken, yumuşak turizm; başka amaçlarla gerçekleştirilen turizm etkinliğinin bir parçası olarak, doğa ile kısa ilişki geçirdikleri bir turizm etkinlikleridir (Aydın Tükeltürk ve Boz, 2013: 8). Dünya Turizm Örgütünün belirtmiş olduğu veriler doğrultusunda; dünyada en fazla ziyaret edilen altıncı ülkesi olan Türkiye, dünya pazarında \%3,5'lik, Avrupa turizm pazarında ise \%6,8'lik payla önemli turizm noktaları arasında yer almaktadır (Ünal Ankaya, vd., 2018: 70).

Ekoturizm kavramı Türkiye'de ilk kez Sekizinci Kalkınma Planında (2001-2005) oluşturulmuştur (Kormaz ve Yavaş, 2020: 17).

- Ormanların işletilmesinde önemli kriterlere yer verilmiştir. Bu kriterler ekosistemin bozulmamasına yönelik olduğu ve oluşturulan projelerin devamlılığı, verimliliği, katılım sağlayan bireylerin amaçladıkları hedefler dikkate alınarak geliştirileceği belirtilmiştir.

- Ekoturizmin geliştirilmesine bağlı olarak, doğal afetlere karşı önlem alınması amacıyla Tabiat Koruma Alanları ve Milli Parklar gibi projelere daha fazla yer verilecektir.

- Tercih edilen turistik alanların yerel yöneticileri turizm faaliyetlerinde aktif rol alması sağlanarak küçük ölçekli işletmelerinde katkı sağlaması hedeflendirilmiştir.

- Turizm faaliyetleri açısından geri planda kalmış alanların gelişimi konusunda çalışmalar daha fazla yer verilicektir.

Ülkemizde ekoturizm faaliyetleri 2002 y1lında İstanbul'da kurulan “Ekoturizm Derneği” ile hızlı bir büyüme göstermiş olup derneğin adı 2006 yılında "Türkiye Ekoturizm ve Sürdürülebilir Turizm Derneği” olarak faaliyetine devam etmiştir (Tutcu, 2021: 9). 2012 yılında bazı illerde Doğa Turizmi Master Planı oluşturularak uygulamaya konulmuştur. 2014 yılında Türkiye, Çevre ve Orman Bakanlığı, içerisinde olan Doğa Koruma ve Milli Parklar Genel Müdürlügünce oluşturulan 40 tane milli park listelenmiştir (Tekin, 2014: 44). Kültür ve 
Turizm Bakanlığı'nca hazırlanmış olan “Türkiye Turizm Stratejisi 2023” isimli evrakta ekoturizme yönelik hedeflere yer verilmiştir (Tutcu, 2021: 10).

Türkiye'nin 2023 stratejilerinde kitle turizm olumsuzluklarından bahsederken, alternatif turizm çeşitlilikleri belirlenmiştir. $\mathrm{Bu}$ stratejilerde ekoturizmin bölgelerinden bahsedilip, doğal kültürel değerlerin üzerinde durulmuştur. Bunun için paydaşlar belirlenmiş; kamu, yerel yönetimler, özel sektör ve sivil toplum kuruluşları yerel halkın katılımının sağlanması amaçlanmıştır. Ekoturizm ile ilgili planlamaların oluşturulmasında özel sektör, sivil toplum kuruluşları önemli katkıda bulunsa da yerel yönetimlerin katkılarıyla bir bütünlük kazanmaktadır (Uysal, 2020: 2).

\section{Yöntem}

Çalışmada nitel bir analiz yöntemi olan bibliyometrik analiz incelemesi ve doküman analiz yöntemi kullanılmıştır. Bu çalışma doğrultusunda basılı ve elektronik kaynaklar incelenmiştir. Bibliyometrik analiz "matematiksel ve istatistiksel yöntemler ile akademik alanda yapılmış çalışmaların anahtar sözcüğü, konusu, yazar sayısı, yayımlanmış yılı gibi bibliyometrik açısından incelenmesidir" (Ardıç Yetiş ve Çokal, 2018: 41). Bibliyometrik analizler belirli bir yıl aralığında yayımlanan makalelerin sayıların belirlenmesi amacıyla olabileceği gibi, herhangi bir makalenin kendisinden sonra gelen araştırmaları ne derece etkilediğinin ortaya konulması şeklinde de olabilmektedir (Temizkan vd., 2015: 398). Doküman analizi ise, yazılı belgelerin içeriğini titizlikle ve sistematik olarak analiz etmek için kullanılan bir nitel araştırma yöntemidir. Doküman analizi, basılı ve elektronik ortamda yayımlanmış çalışmaların incelenmesi ve değerlendirmesinde kullanılan sistemli bir yöntemdir (Kıral, 2020: 173). Kullanılan analizler doğrultusunda ekoturizm projeleri taranmış olup tarama sonucunda 22 projeye erişim sağlanmıştır. Çalışmalar yıllara, kapsadığı bölgelere, amaç, sonuç birimleri ile detaylı incelenmiştir.

\section{Bulgular}

Tablo 1 'de Türkiye'de ekoturizmi geliştirmek amacıyla oluşturulmuş projelerin listesi verilmiştir. Yer alan projelerin ne olduğu, hangi amaçla bu proje üzerinde çalışmalar yapıldığı incelenmiştir. 
Tablo 1. Ekoturizm Amaçlı Yapılan Çalışmalar

\begin{tabular}{|c|c|c|c|c|}
\hline Projeler & Yll & Bölgeler & Amaç & Sonuç \\
\hline $\begin{array}{c}\text { ATAK } \\
\text { (Akdeniz-Ege } \\
\text { Turizm Altyapısı } \\
\text { Kıyı Yönetim) } \\
\text { Projesi }\end{array}$ & 1989 & $\begin{array}{l}\text { Balıkesir, İzmir, } \\
\text { Aydın, Muğla, } \\
\text { Antalya kıyı } \\
\text { kesiminde yaklaşık } \\
100 \text { belediyeyi } \\
\text { kapsamaktadır. }\end{array}$ & $\begin{array}{l}\text { Proje dahilinde belirlenmiş } \\
\text { ilçe ve köylerin yer aldığı } \\
2000 \text { km. kıyı şeridini } \\
\text { kapsamaktadır. }\end{array}$ & $\begin{array}{c}\text { Yerleşim yerlerinin \%76’sında } \\
\text { fosseptik çukur yetersizliği, \%13’ünde } \\
\text { kanalizasyon şebekesi eskimesi, } \\
\text { \%11'inde ise yeni kanalizasyon } \\
\text { şebekesiyle atık suların arıtılmadan } \\
\text { denize verilerek çevresel alt yapı } \\
\text { eksiklerinin ortadan kaldırılması } \\
\text { sağlanmıştır. }\end{array}$ \\
\hline $\begin{array}{c}\text { Yayla Turizmi } \\
\text { Projesi }\end{array}$ & 1990 & $\begin{array}{l}\text { Karadeniz, } \\
\text { Gaziantep-İslâhiye } \\
\text { Huzurlu, Antalya- } \\
\text { İbradi Maşata ve } \\
\text { Manisa-Spil yaylaları }\end{array}$ & $\begin{array}{c}\text { Doğu Karadeniz ve } \\
\text { Akdeniz yaylalarından } \\
\text { başlayarak İç Anadolu, } \\
\text { Ege, Güneydoğu Anadolu } \\
\text { Bölgelerini kapsamaktadır. }\end{array}$ & $\begin{array}{c}\text { Yayla Turizm Projesi ile } 26 \text { yayla } \\
\text { merkezi belirlenerek ekoturizm } \\
\text { potansiyeli artırmak amaçlanmıştır. }\end{array}$ \\
\hline $\begin{array}{l}\text { Kuş Gözlemciliği } \\
\text { Özel Kuş Alanları } \\
\text { Projesi }\end{array}$ & 1990 & $\begin{array}{c}\text { Meriç, Marmara, } \\
\text { Susurluk, Kuzey Ege, } \\
\text { Gediz, Büyük-Küçük } \\
\text { Menderes, Batı } \\
\text { Akdeniz, Burdur- } \\
\text { Kapalı, Antalya, } \\
\text { Akarçay, Sakarya, } \\
\text { Kızılırmak, } \\
\text { Yeşilırmak, Doğu } \\
\text { Akdeniz, Seyhan, } \\
\text { Ceyhan, Fırat, Dicle } \\
\text { Havzaları }\end{array}$ & $\begin{array}{l}1989 \text { yılında başlatılan ve } \\
\text { dünyanın birçok ülkesinde } \\
\text { yürütülen proje Türkiye'de } \\
2002 \text { yılında kurulan } \\
\text { Doğal Hayatı Koruma } \\
\text { Derneği tarafından } \\
\text { yürütülmektedir. }\end{array}$ & $\begin{array}{l}\text { Türkiye’deki toplam kuş türlü sayısı } \\
\text { Avrupa'da bulunan kuş türleri } \\
\text { kadardır. Kuş alanlarının kamuoyu } \\
\text { bilinci oluşturarak bu alanların } \\
\text { gelişmesi sağlanmaktadır. }\end{array}$ \\
\hline $\begin{array}{l}\text { Mavi Bayrak } \\
\text { Projesi }\end{array}$ & 1993 & $\begin{array}{c}\text { Akdeniz kıyı } \\
\text { şeridinde yoğun } \\
\text { olarak başlayarak tüm } \\
\text { kıyı turizmi }\end{array}$ & $\begin{array}{l}1985 \text { yılında Fransa'da, } \\
\text { uluslararası sivil toplum } \\
\text { örgütü tarafından } \\
\text { geliştirilmiştir. Yüzme } \\
\text { suyu kalitesi ve çevre } \\
\text { temizliği temel alınarak } \\
\text { mavi bayrak verilmesiyle } \\
\text { başlamıştır. }\end{array}$ & $\begin{array}{l}\text { Türkiye’de Mavi Bayrak Projesi, } 1996 \\
\text { yılından itibaren, Türkiye Çevre } \\
\text { Eğitim Vakfı, Sağlık ve Kültür Turizm } \\
\text { Bakanlığı tarafından yürütülmektedir. }\end{array}$ \\
\hline
\end{tabular}


Turistik Ürün Çeşitlendirmesi Kapsamında Ekoturizme Yönelik Projelerin Değerlendirilmesi

\begin{tabular}{|c|c|c|c|c|}
\hline $\begin{array}{c}\text { Belek Yönetim } \\
\text { Planı }\end{array}$ & 1996 & Antalya-Belek & $\begin{array}{c}\text { Kültürel ve doğal } \\
\text { alanlarını korumak } \\
\text { amacıyla oluşturulmuştur. }\end{array}$ & $\begin{array}{c}\text { Dünya Doğayı Koruma Birliği ve } \\
\text { Dünya Bankası ile birlikte girişimcilik } \\
\text { potansiyeli artırılmaktır. }\end{array}$ \\
\hline $\begin{array}{l}\text { Milli Parklar ve } \\
\text { Çevre Eğitimi } \\
\text { Projesi }\end{array}$ & 1999 & Antalya, Rize & $\begin{array}{l}\text { Milli parkların ekoturizm } \\
\text { potansiyellerini ortaya } \\
\text { koymak amaçlanmıştır. }\end{array}$ & $\begin{array}{l}\text { Antalya Termessos ve Güllük Dağı } \\
\text { Milli Parkı } 2000 \text { yılı itibariyle Rize’de } \\
\text { Kaçkar Dağları Milli Parkı içerisinde } \\
\text { üniversite öğrencileri ve turist } \\
\text { rehberlerine eğitim programları } \\
\text { düzenlenmiştir. }\end{array}$ \\
\hline $\begin{array}{c}\text { Yeşil Küre } 21 \\
\text { Programı }\end{array}$ & 2001 & $\begin{array}{l}\text { Kriterlere uyum } \\
\text { sağlayan tüm turizm } \\
\text { işletmeleri }\end{array}$ & $\begin{array}{c}\text { Havaalanları, SPA } \\
\text { merkezleri, golf alanları, } \\
\text { marinalar, oteller, } \\
\text { restoranlar gibi kitle ve } \\
\text { sürdürülebilir turizm } \\
\text { alanında faaliyet gösterilen } \\
\text { programdır. }\end{array}$ & $\begin{array}{l}\text { Kâr amaçlı organizasyon olan Green } \\
\text { Globe International, INC. tarafından } \\
\text { yürütülmektedir. }\end{array}$ \\
\hline $\begin{array}{c}\text { Buğday Ekolojik } \\
\text { Yaşamı } \\
\text { Destekleme } \\
\text { Derneği Tarım- } \\
\text { Turizm-Takas } \\
\text { (TATUTA) } \\
\text { Projesi }\end{array}$ & 2003 & $\begin{array}{c}\text { Antalya, Muğla, } \\
\text { Burdur, Erzincan, } \\
\text { Kastamonu, Manisa, } \\
\text { Gümüşhane, Amasya, } \\
\text { Çanakkale, Tokat, } \\
\text { Artvin }\end{array}$ & $\begin{array}{c}\text { Şehir hayatından } \\
\text { uzaklaşmak isteyen } \\
\text { bireylerin, doğal ve } \\
\text { organik yiyeceklerin hem } \\
\text { nasıl yetişeceğini görmek } \\
\text { hem de beslenme için yerli } \\
\text { ve yabancı turistlerin } \\
\text { istekleri doğrultusunda } \\
\text { oluşturulmuştur. }\end{array}$ & $\begin{array}{l}\text { Proje kapsamında } 92 \text { çiftlik } \\
\text { bulunmaktadır. Projeye katılım } \\
\text { sağlayan konukların çiftlik sahipleri } \\
\text { tarafından konaklama, yeme-içme, } \\
\text { günlük ihtiyaçları karşılanmaktadır. }\end{array}$ \\
\hline PAN Parks & 2006 & Küre Dağları & $\begin{array}{l}2006 \text { yılında oluşturulan } \\
\text { ekoturizm sertifikasyon } \\
\text { programıdır. }\end{array}$ & $\begin{array}{l}\text { Doğal alanların korunmasında turizmin } \\
\text { araç olması amaçlanmıştır. } 8 \text { Ekim } \\
2012 \text { tarihinde Küre Dağları Parkı, } \\
\text { PAN Parks ödülü almıştır. }\end{array}$ \\
\hline $\begin{array}{c}\text { Yeşil Yıldız } \\
\text { Projesi }\end{array}$ & 2006 & $\begin{array}{l}\text { Kriterlere uyum } \\
\text { sağlayan tüm } \\
\text { konaklama } \\
\text { işletmeleri }\end{array}$ & $\begin{array}{l}\text { Eko-etiket ve yeşil yıldız } \\
\text { işletmelerin Kültür ve } \\
\text { Turizm Bakanlığı } \\
\text { aracılığıyla Çevre Dostu } \\
\text { Belgesi verilmektedir. }\end{array}$ & $\begin{array}{l}\text { Çevre bilincinin geliştirilmesi, su ve } \\
\text { enerji tasarrufu sağlanabilmesi, } \\
\text { atıklarda geri dönüşümü } \\
\text { yaygınlaştırmak için düzenlenmiştir. }\end{array}$ \\
\hline
\end{tabular}




\begin{tabular}{|c|c|c|c|c|}
\hline $\begin{array}{c}\text { GAP Ekoturizm } \\
\text { Koridoru }\end{array}$ & 2007 & $\begin{array}{l}\text { Adıyaman, Batman, } \\
\text { Diyarbakır, } \\
\text { Gaziantep, Kilis, } \\
\text { Mardin, Siirt, Şırnak, } \\
\text { Şanlıurfa }\end{array}$ & $\begin{array}{l}\text { Yerel halkın gelir ve hayat } \\
\text { standartlarının } \\
\text { yükseltilmesi } \\
\text { amaçlanmıştır. }\end{array}$ & $\begin{array}{c}\text { Barajlar, hidroelektrik santraller, } \\
\text { sulama yapıları ile sınırlandırmayarak } \\
\text { tarım, sanayi, kentsel ve kırsal alt yapı, } \\
\text { eğitim, sağlık, kültür gibi } \\
\text { sosyoekonomik yatırımı } \\
\text { kapsamaktadır. }\end{array}$ \\
\hline $\begin{array}{l}\text { Termal Turizm } \\
\text { Kentleri Projesi }\end{array}$ & 2007 & $\begin{array}{c}\text { Çanakkale, Balıkesir, } \\
\text { Yalova, } \\
\text { Afyonkarahisar, } \\
\text { Kütahya, Eskişehir, } \\
\text { Ankara, Uşak, İzmir, } \\
\text { Manisa, Aydın, } \\
\text { Denizli, Yozgat, } \\
\text { Kırşehir, Nevşehir, } \\
\text { Amasya, Sivas, } \\
\text { Tokat, Erzincan, } \\
\text { Bilecik, Kocaeli, } \\
\text { Bolu, Düzce, Sakarya }\end{array}$ & $\begin{array}{l}\text { Termal kaynaklara sahip } \\
\text { yeni alanların tespit } \\
\text { edilmesiyle bulunan illerin } \\
\text { termal turizmden } \\
\text { yararlanılması } \\
\text { hedeflenmiştir. }\end{array}$ & $\begin{array}{c}\text { Proje kapsaminda termal kaynaklara } \\
\text { sahip kentlerin potansiyellerini } \\
\text { belirlemektir. }\end{array}$ \\
\hline $\begin{array}{c}\text { Beyaz Yıldız } \\
\text { Programı }\end{array}$ & 2008 & $\begin{array}{l}\text { Kriterlere uyum } \\
\text { sağlayan tüm } \\
\text { konaklama } \\
\text { işletmeleri }\end{array}$ & $\begin{array}{l}\text { Sealed Air ve Türkiye } \\
\text { Otelciler Federasyonu'yla } \\
\text { çevre kirliliğini en aza } \\
\text { indirilmesi amaciyla } \\
\text { oluşturulmuştur. }\end{array}$ & $\begin{array}{l}\text { Turistik işletmelerde kontrolsüz } \\
\text { tüketimi engelleyerek kullanılan su, } \\
\text { elektrik, enerji, kimyasal ve katı atık } \\
\text { miktarının kontrol altına alınması } \\
\text { amaçtır. }\end{array}$ \\
\hline Cittaslow Ağı & 2009 & $\begin{array}{l}\text { İzmir-Seferihisar, } \\
\text { Muğla-Akyaka, } \\
\text { Isparta-Eğirdir, } \\
\text { Çanakkale-Gökçeada, } \\
\text { Sinop-Gerze, Bolu- } \\
\text { Göynük, Şanlıurfa- } \\
\text { Halfeti, Bolu- } \\
\text { Mudurnu, Ordu- } \\
\text { Perşembe, Artvin- } \\
\text { Savşat, Sakarya- }\end{array}$ & $\begin{array}{l}\text { Türkiye } 2009 \text { yılında } \\
\text { başlayan nüfusun } \\
\text { 50.000'in altında kimlik, } \\
\text { gelenek, görenek, kültür ve }\end{array}$ & $\begin{array}{c}\text { Proje kapsamında çevre, altyapı, yerel } \\
\text { üretimi korumak, misafirperverlik, } \\
\text { farkındalık, slowfood hareketiyle } \\
\text { belirlenmektedir. }\end{array}$ \\
\hline
\end{tabular}




\begin{tabular}{|c|c|c|c|c|}
\hline & & $\begin{array}{c}\text { Taraklı, Erzurum- } \\
\text { Uzundere, Kırklareli- } \\
\text { Vize, Isparta-Yalvaç, } \\
\text { Aydın-Yenipazar, } \\
\text { Muğla-Köyceğiz, } \\
\text { Bitlis-Ahlat, Ankara- } \\
\text { Güdül }\end{array}$ & $\begin{array}{c}\text { miraslarının koruma altına } \\
\text { alınmasıdır. }\end{array}$ & \\
\hline $\begin{array}{l}\text { Yeşil Anahtar } \\
\text { (Green Key) } \\
\text { Programı }\end{array}$ & 2011 & $\begin{array}{l}\text { Antalya, İstanbul, } \\
\text { Çanakkale, Aydın, } \\
\text { Bursa, Balıkesir, } \\
\text { Ankara, Adana, } \\
\text { İzmir, Samsun, Ordu, } \\
\text { Trabzon, Nevşehir, } \\
\text { Mersin, Muğla }\end{array}$ & $\begin{array}{l}\text { Türkiye de yer alan turizm } \\
\text { işletmelerin } \\
\text { sürdürebilirliğinin ve çevre } \\
\text { duyarlılığının } \\
\text { benimsenmesiyle, iklim } \\
\text { değişikliklerinin önüne } \\
\text { geçmek hedeflenmiştir. }\end{array}$ & $\begin{array}{l}\text { Çevresel zararların en aza indirilmesi, } \\
\text { çevre koruma tedbirlerine farkındalık } \\
\text { kazandırmaya yönelik oluşturulmuş } \\
\text { proje TÜRÇEV tarafından her yıl } \\
\text { yenilenmektedir. }\end{array}$ \\
\hline Yeşil Yol Projesi & $\begin{array}{l}2014 \\
2018\end{array}$ & $\begin{array}{l}\text { Samsun, Ordu, } \\
\text { Giresun, Gümüşhane, } \\
\text { Bayburt, Trabzon, } \\
\text { Rize, Artvin }\end{array}$ & $\begin{array}{c}\text { Doğu Karadeniz } \\
\text { bölgesinde sürdürebilirliği } \\
\text { artırarak mevsimsel } \\
\text { kısalığı, ulaşım } \\
\text { sorunlarında yaşanan } \\
\text { problemleri azaltmak } \\
\text { amacıyla oluşturulmuştur. }\end{array}$ & $\begin{array}{l}\text { Yerli ve yabancı turistlerin güzergâh } \\
\text { boyunca seyahat etmesine olanak } \\
\text { sağlayarak doğayla bütünleştirmektir. }\end{array}$ \\
\hline $\begin{array}{c}\text { İnanç Turizm } \\
\text { Projesi }\end{array}$ & 2017 & $\begin{array}{l}\text { Aydın, Denizli, } \\
\text { Muğla }\end{array}$ & $\begin{array}{c}\text { Müslümanlık- } \\
\text { Hıristiyanlık-Musevilik } \\
\text { açısından önemli ziyaret } \\
\text { merkezlerini çevre, ulaşım } \\
\text { açılardan iyileştirilerek } \\
\text { ziyaretçi sayısının } \\
\text { artırılması } \\
\text { hedeflenmektedir. }\end{array}$ & $\begin{array}{l}\text { Anadolu'da tespit edilmiş } 316 \text { eserden; } \\
167 \text { eser İslam, } 129 \text { eser Huristiyan ve } \\
20 \text { eser Musevi dinine aittir. }\end{array}$ \\
\hline \multirow[t]{2}{*}{ İpek Yolu Projesi } & $\mathrm{X}^{*}$ & $\begin{array}{l}\text { Aksaray, Nevşehir, } \\
\text { Antalya, Denizli, } \\
\text { Malatya, Burdur }\end{array}$ & $\begin{array}{l}\text { "Diyalog Yolu” olarak da } \\
\text { bilinmektedir. } \\
\text { Kervansarayların ve Tarihi } \\
\text { İpek yolunun } \\
\text { canlandırılması } \\
\text { amaçlanmıştır. }\end{array}$ & $\begin{array}{l}2886 \text { sayılı Devlet İhale Kanunu'na } \\
\text { göre } 11 \text { Kervansaray incelenerek, } \\
\text { restore et-işlet-devret modeli } \\
\text { çerçevesinde turizme kazandırılmıştır. }\end{array}$ \\
\hline & & & $\begin{array}{l}\text { Ekoturizm çerçevesinde } \\
\text { turistlerin daha fazla vakit }\end{array}$ & \\
\hline
\end{tabular}

* Projelerin gerçekleştiği yıl bilgisine erişim sağlanamadığı için " $x$ ” olarak belirtilmektedir. 


\begin{tabular}{|c|c|c|c|c|}
\hline $\begin{array}{l}\text { Dağ ve Doğa } \\
\text { Yürüyüşü } \\
\text { Projesi }\end{array}$ & $X$ & $\begin{array}{l}\text { Akdeniz kıyı şeridi, } \\
\text { Ege, Marmara ve } \\
\text { Karadeniz bölgesi }\end{array}$ & $\begin{array}{c}\text { geçirmelerinin sağlanması } \\
\text { maksadıyla } \\
\text { gerçekleştirilmektedir. }\end{array}$ & $\begin{array}{l}\text { Turizm alanlarını korumak, yörelerin } \\
\text { ekonomik ve sosyal katkılarını } \\
\text { sağlamıştır. }\end{array}$ \\
\hline $\begin{array}{c}\text { Akarsu Turizmi } \\
\text { Projesi }\end{array}$ & $X$ & $\begin{array}{l}\text { Doğu Karadeniz, } \\
\text { Doğu Anadolu ve } \\
\text { Akdeniz }\end{array}$ & $\begin{array}{l}\text { Rafting, kano ve nehir } \\
\text { kayağı amacıyla uygun } \\
\text { olan akarsuların turizm } \\
\text { açısından } \\
\text { değerlendirilmesidir. }\end{array}$ & $\begin{array}{l}\text { Antalya-Manavgat Çayı, Artvin-Çoruh } \\
\text { Nehri, Artvin-Altıparmak Çayı, Rize- } \\
\text { Fırtına Deresi gibi bölgelerin turizme } \\
\text { kazandırılmasıdır. }\end{array}$ \\
\hline $\begin{array}{l}\text { Bisiklet Tur } \\
\text { Güzergâhlarının } \\
\text { Geliştirilmesi } \\
\text { Projesi }\end{array}$ & $X$ & $\begin{array}{l}\text { Konya, Sakarya, } \\
\text { Antalya, İzmir, } \\
\text { Samsun, Eskişehir, } \\
\text { Trabzon, İstanbul }\end{array}$ & $\begin{array}{c}\text { Bisiklet turlarının } \\
\text { yapılması planlanan } \\
\text { parkurların belirlenmesi ve } \\
\text { bu parkurların üzerinde } \\
\text { zorunlu düzenlemelerin } \\
\text { sağlanması amaçlanmıştır. }\end{array}$ & $\begin{array}{l}\text { Master planlarında bisiklet yolları ile } \\
\text { rotaların oluşturulması için çalışmalar } \\
\text { düzenlenmektedir. }\end{array}$ \\
\hline $\begin{array}{c}\text { Mağara Turizmi } \\
\text { Projesi }\end{array}$ & $X$ & $\begin{array}{l}\text { Kriterlere uyum } \\
\text { sağlayan tüm iller }\end{array}$ & $\begin{array}{l}\text { Türkiye'de turizmi } \\
\text { bölgelere ve yılın } 12 \text { ayına } \\
\text { yaygınlaştırılması } \\
\text { amacıyla oluşturulmuştur. }\end{array}$ & $\begin{array}{l}\text { Türkiye'nin } 40.000 \text { adet civarında } \\
\text { mağarası bulunmaktadır. Bu } \\
\text { mağaralardan ancak } 1.200 \text { tanesi } \\
\text { incelenebilmiştir. }\end{array}$ \\
\hline
\end{tabular}

Tablo 1'de Türkiye'nin ulusal ve uluslararası alanda çalışmaları artırmak amacıyla yapılmış projelerden bahsedilmiştir. Kitle turizmin oluşturduğu olumsuzlukları en aza indirmek ekonomik ve yerel halkı kalkındırma amacı açısından önemlidir. Bireylerin günümüzde doğal alanlara yoğunlaştığı belirtilebilir (Gök ve Özkoç, 2020; Tetik, 2012; Kutluay Tutar, 2015; Gökçe vd., 2015; Akyurt, 2019; Tutcu, 2021; Şekerli, 2018; Ünal Ankaya ve Gülgün Aslan, 2019; Aslan ve Güneş, 2015; Baykal ve Çimen, 2015; İstanbullu Dinçer vd., 2015; Satar, 2016; Doruk, 2019; Başer ve Başçı, 2012; Aytuğ, 2016; Şahin ve Kutlu, 2014). 
Şekil 1. Ekoturizm Amaçlı Yapılan Çalışmaların Senelere Göre Dağılımı

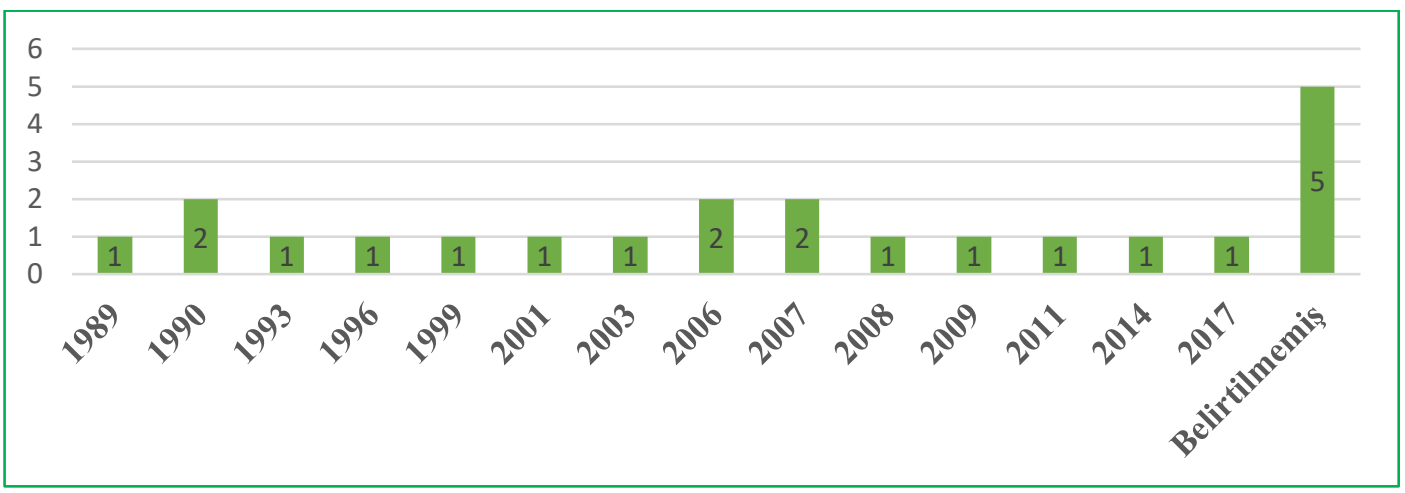

Tablo 3. Ekoturizm Amaçlı Yapılan Çalışmaların Senelere Göre Yüzde-Frekans Dağılımı

\begin{tabular}{|c|c|c|}
\hline Yillar & $\mathbf{n}$ & $\%$ \\
\hline 1989 & 1 & 4,5 \\
\hline 1990 & 2 & 9 \\
\hline 1991 & - & - \\
\hline 1992 & - & - \\
\hline 1993 & 1 & 4,5 \\
\hline 1994 & - & - \\
\hline 1995 & - & - \\
\hline 1996 & 1 & 4,5 \\
\hline 1997 & - & - \\
\hline 1998 & - & - \\
\hline 1999 & 1 & 4,5 \\
\hline 2000 & - & - \\
\hline 2001 & 1 & 4,5 \\
\hline 2002 & - & - \\
\hline 2003 & 1 & 4,5 \\
\hline 2004 & - & - \\
\hline 2005 & - & - \\
\hline 2006 & 2 & 9 \\
\hline 2007 & 2 & 9 \\
\hline 2008 & 1 & 4,5 \\
\hline 2009 & 1 & 4,5 \\
\hline 2010 & - & - \\
\hline 2011 & 1 & 4,5 \\
\hline
\end{tabular}




\begin{tabular}{|c|c|c|}
\hline $\mathbf{2 0 1 2}$ & - & - \\
\hline $\mathbf{2 0 1 3}$ & - & - \\
\hline $\mathbf{2 0 1 4}$ & 1 & -5 \\
\hline $\mathbf{2 0 1 5}$ & - & - \\
\hline $\mathbf{2 0 1 6}$ & - & 4,5 \\
\hline $\mathbf{2 0 1 7}$ & 1 & 23 \\
\hline Belirtilmemiş & 5 & 100 \\
\hline Toplam & 22 & -5 \\
\hline
\end{tabular}

Şekil 1'de ekoturizm projelerinin gerçekleştirdiği yıllara göre dağılımı verilmiştir. Çalışma doğrultusunda 22 projeye yer verilmiştir. Projeler incelendiğinde 5 tanesinin sene ifadesine yer vermediği gözlemlenmektedir. Tablo 1'de ise ekoturizm amaçlı yapılan çalışmaların senelere göre yüzde frekans dağılımına yer verilmiştir.

Tablo 4. Ekoturizm Projelerinin Turizm Türüne Göre Yüzde-Frekans Dağılımı

\begin{tabular}{|l|c|c|}
\hline \multicolumn{1}{|c|}{ Turizm Türü } & n & \% \\
\hline Deniz Temelli Turizm & 4 & 18 \\
\hline Yayla Turizmi & 1 & 4,5 \\
\hline Kültür Turizmi & 2 & 9 \\
\hline Doğa Turizmi & 10 & 45 \\
\hline Sağlık Turizmi & 1 & 4,5 \\
\hline İnanç Turizmi & 1 & 4,5 \\
\hline Macera Turizmi & 3 & 13,5 \\
\hline Toplam & 22 & 100 \\
\hline
\end{tabular}

Tablo 4'te ekoturizm projelerinin turizm ürün çeşitlendirmesi kapsamında dağılımına yer verilmiştir. En fazla \%45 oranı ile doğa turizminin, \%18 ile yayla turizmi en az oranı karşımıza çıkarmaktadır. Sağlık turizmi ve inanç turizminin oranları ise aynı olup, \%4,5 dir.

Tablo 5. Ekoturizm Projelerinin Bölgelere Göre Yüzde-Frekans Dağılımı

\begin{tabular}{|l|c|c|}
\hline \multicolumn{1}{|c|}{ Bölgeler } & n & \% \\
\hline Akdeniz Bölgesi & 15 & 11,6 \\
\hline Doğu Anadolu Bölgesi & 7 & 5,4 \\
\hline Ege Bölgesi & 27 & 21 \\
\hline
\end{tabular}


Turistik Ürün Çeşitlendirmesi Kapsamında Ekoturizme Yönelik Projelerin Değerlendirilmesi

\begin{tabular}{|l|c|c|}
\hline Güneydoğu Anadolu Bölgesi & 12 & 9,3 \\
\hline İç Anadolu Bölgesi & 12 & 9,3 \\
\hline Karadeniz Bölgesi & 34 & 26 \\
\hline Marmara Bölgesi & 18 & 14 \\
\hline Belirtilmemiş & 4 & 3,1 \\
\hline Toplam & 129 & 100 \\
\hline
\end{tabular}

Tablo 5'te ekoturizm projelerinin bölgelere göre dağılımına yer verilmiştir. En fazla Karadeniz bölgesinin \%26 kısma sahip olduğu görülmektedir. Karadeniz Bölgesini \%21 oranı ile Ege bölgesi takip etmektedir. Ayrıca \%3,1’lik kısmı ise hangi bölgeleri kapsadığı belirtilmemiştir.

Tablo 6. Ekoturizm Projelerinin Etkilerine Göre Dağılımı

\begin{tabular}{|c|c|c|}
\hline Ekonomik & Çevresel & Sosyo-Kültürel \\
\hline $\begin{array}{ll}\text { - } & \text { Yeşil Küre } 21 \text { Programı } \\
\text { - } & \text { GAP Ekoturizm Koridoru } \\
\text { • } & \text { Termal Turizm Kentleri } \\
& \text { Projesi } \\
\text { - } & \text { İnanç Turizm Projesi } \\
\text { - } & \text { İpek Yolu Projesi } \\
\text { - } & \text { Dağ ve Doğa Yürüyüşü } \\
\text { - } & \text { Projesi } \\
\text { - } & \text { Bisarsiklet Tur Güzergâhlarının } \\
& \text { Geliştirilmesi Projesi } \\
\text { - } & \text { Mağara Turizmi Projesi }\end{array}$ & $\begin{array}{ll}\text { - } & \text { ATAK (Akdeniz-Ege } \\
\text { Turizm Altyapısı Kıyı } \\
\text { - } & \text { Yönetim) Projesi } \\
\text { - } & \text { Kuş̧a Turizmi Projesi } \\
\text { - } & \text { Kuş Alanlanciliği Özel Projesi } \\
\text { - } & \text { Yeşil Yıldız Projesi } \\
\text { - } & \text { PAN Parks, } \\
\text { - } & \text { Beyaz Yıldız Programı } \\
\text { - } & \text { Cittaslow Ağı } \\
\text { - } & \text { Yeşil Anahtar (Green } \\
\text { Key) Programı } \\
\text { Bisiklet Tur } \\
\text { Güzergâhlarının } \\
\text { Geliştirilmesi Projesi }\end{array}$ & $\begin{array}{ll}\text { - } & \text { Belek Yönetim Planı } \\
\text { - } & \text { Milli Parklar ve Çevre } \\
& \text { Eğitimi Projesi } \\
\text { - } & \text { Buğday Ekolojik Yaşamı } \\
& \text { Destekleme Derneği } \\
& \text { Tarım-Turizm-Takas } \\
\text { (TATUTA) Projesi }\end{array}$ \\
\hline
\end{tabular}

Tablo 6.1. Ekoturizm Projelerinin Etkilerine Göre Yüzde-Frekans Dağılımı

\begin{tabular}{|c|c|c|}
\hline Dağılım & n & \% \\
\hline Ekonomik & 9 & 41 \\
\hline
\end{tabular}




\begin{tabular}{|c|c|c|}
\hline Çevresel & 10 & 45 \\
\hline Sosyo-Kültürel & 3 & 14 \\
\hline Toplam & 22 & 100 \\
\hline
\end{tabular}

Tablo 6' da ekoturizm projelerinin ekonomik, çevresel ve sosyo-kültürel dağılımlarının yüzde frekansına yer verilmiştir. En fazla \%45 oranı ile çevresel, \%14 ile sosyo-kültürel en az oran ile karşımıza çıkmaktadır.

\section{Ekoturizmin Etkileri}

Ekoturizmin oluşumunda, çevresel (doğaya zararı en aza indirmek), ekonomik (gelirlerin yerel halka iletilmesi) ve sosyo-kültürel (doğal değerlerin korunması ve geliştirilmesi) konularda sürdürebililiği sağlamak amaçlanılmaktadır (Turpcu ve Çlikkanat, 2019). Ekoturizm faaliyetleri bir bölgede ancak planlı bir şekilde uygulandığı ve geliştirildiği doğrultusunda sürdürebilirliğinden bahsedilebilir.

\subsection{Ekoturizmin Çevresel Etkileri}

Ekoturizmin çevresel etkileri turistik ürünün oluşumunda, turizm faliyetlerinde olumlu veya olumsuz olarak etkilemektedir (Yılmaz, 2008: 79). Ekoturizm, çevresel kaynaklar doğrultusunda gelişen doğal alanların korumasına yönelik oluşturulmuş yerel halk ve turistlerin bilinçlendirildiği bir turizm çeşididir. (Tekin, 2014: 27-79).

Çevre üzerinde olumlu etkiler dışında, olumsuz etkilerde önemli konulardan biridir. Turistlerin denetim dışı davranışları sonucu ortaya çıkan orman yangınları, bitki ve vahşi hayvan yerleşimine zarar verebilmektedir. Gürültü, görüntü kirliliği, çöpler gibi yaban hayatını ve ziyaretçileri rahatsız ederek ve çevreye zarar vererek doğal alanları olumsuz etkilemektedir (Tekin, 2014: 27; Y1lmaz, 2008: 81; Tetik, 2012: 83). Brezilya ekoturistlerinin gezi esnasında resim çekmesi ve Belize sahilinde motor kullanmaları doğrultusunda oluşan gürültü ile tropikal kuşların bu alanlardan göç etmelerine sebep olmaktadır (Herbig ve O’Hara, 1997: 234). 


\subsection{Ekoturizmin Sosyo-Kültürel Etkileri}

Ekoturistler ziyaret ettiği destinasyonlarda o bölgenin kültürleri ile yakından ilgilenmektedirler. Sosyo-kültürel etkilerine olumlu örnek, Fiji'de bulunan iki köyün ekoturizm açısından yoğun sürdüğüne yönelik bir araştırma gerçekleşmiştir. Ekoturizmin köyde gelişmesiyle birlikte köyde bulunan bireylerin eğitim ve ekonomik düzeyinde olumlu etkiler meydana gelmektedir. Toplumun mecburi ihtiyaçları dışında kalan harcanabilir gelirin olması, bireylerin gelecekteki beklentilerinde olumlu yönde etkilediği belirtilmiştir (Tetik, 2012: 90).

Bölgeki yerel halk, turizm faaliyetlerini benimsemediği zaman bu durumdan olumsuz etkilendiği belirtilmiştir. Bu olumsuz etkiler toplumun dışlanmasından kaynaklı olabileceği gibi ekoturizmin geniş alana yayılmamasından da oluşabileceği belirtilmiştir. Bölgede bulunan bazı doğal ve kültürel değerler, gelenekler, turizm faaliyetleri sonucunda da olumsuz etkilenebilmektedir (Dinçer Şen, 2010: 125). Özellikle festivaller kültürel değerlerin etkinlik olarak turistlere sunulmasıyla, değerlerin orijinal yapısını ve kültürel bozulmalarına neden olabilmektedir. (Tetik,2012: 91).

\subsection{Ekoturizmin Ekonomik Etkileri}

Bir ülkede doğal kaynakların kullanımı doğrultusunda yatırımın ekonomik etkileri, çevresel etkilere göre belirleyici unsur içermektedir (Y1lmaz,2008: 77). Ekoturizmin olumlu etkileri; mal ve döviz kazancı sağlayarak ülkelerin gelişmesini sağlar. Yerel ürünlere karşı talebi artırır ve ürünlerin satılmasına fırsat yaratarak ekonomiye katkı sağlar. Tarıma elverişli toprakların doğal bitki örtüsü ile kaplanmasına olanak verir. Turizmle ilgili konaklama, restoran, hediye eşya satan dükkânların bulunması gelişmede önemli rol oynar. Ulaşım ve iletişim altyapıların gelişmesine olanak sağlar. Elde edilen gelirin ekolojik alanlarda kullanılması için politik ve finansal destek sağlar (Y1lmaz, 2008: 78; Güngör Özkök ve Çoban, 2009: 595; Dinçer Şen, 2010: 122).

Ekoturizmin olumsuz etkileri; mevsimsel özelliğinin olması, ekonomik ve siyasi olaylara bağlı olması sebebiyle yerel halk bütün yıl boyunca gelir kazanamamaktadır. Ayrıca bölgede bulunan işletmelerin su ve enerji kaynaklarını aşırı tüketmeleri nedeni ile bölgede fiyatların artışına ayrıca 
su ve elektrik kesintilerine sebep olabilmektedir (Y1lmaz, 2008: 78; Tetik, 2012: 100; Kasalak ve Akınc1, 2015: 232).

\section{Sonuç}

Turizm sektöründe ekoturizm hızlı büyüyen pazar yapısına sahiptir. Ekoturizmin popülerliği arttıkça kalkınmakta olan ülkelerin ekoturizme yönelik eğilimi artış göstermektedir. Türkiye'nin sürdürebilirlik açısından ekoturizm potansiyelinin değerlendirilmesinde yürütülen projeler önemlidir. Bu çalışmada elde edilen veriler neticesinde Türkiye'de ekoturizm alanında yapılmış 22 tane projeye erişim sağlanmıştır.

Nitekim bu alanlar için yürütülen çalışmaların plansız yürütülmesinin oluşturduğu dezavantajların bu alanlara geri dönüşü olmayan zararlar vermektedir. Turizm projeleri vasitasıyla bireylerin bilgilendirilmesi ve bilinçli toplum oluşumunda önemli rol oynamaktadır. Şu an ülkemizde Covid19 salgını sonrasında doğal alanlara karşı talebin yoğunluğu gözlemlenmiştir.

Yukarıda yapılan veriler 1şı̆̆ında öneriler şu şekilde sunulabilir.

- $\quad$ Yerel halkın doğal alanlara yoğun ilginin artmasıyla her şehir için ekoturizm potansiyelleri değerlendirip alt yapı ve üst yapı çalışmalara yoğunlaştırabilir. Çekicilik unsurları artırılabilir.

- Kültürel mirasın korunması adına, el sanatları, gastronomi, yöresel gelenek ve göreneklerin de yaşatılması gerekmektedir. Ekoturizm projeleriyle birleştirerek önem bir pazar oluşturulabilir.

- $\quad$ Bölge halkı için gerekli tanıtım ve pazarlama sunularak bilinçli ekoturizm pazarı oluşturulmalıdır.

- $\quad$ Bir turizm çeşidi olarak düşünülmektense gelecek kuşaklara doğal alanların bırakılması hedef alınarak ilerletilmelidir

- $\quad$ Uygulanan projeler geliştirilerek ekoturizm talebini artırılabilir. 


\section{Kaynakça}

Akay, B ve Zengin, B. (2012). Ekoturizm Kaynaklarının Geliştirilmesi: Doğu Marmara Bölgesi Örneği, KMÜ Sosyal ve Ekonomik Araştırmalar Dergisi, 14 (23): 115-122. Erişim adresi:https://www.researchgate.net/publication/259451537_Development_of_Ecotourism_Sour ce_East_Marmara_Example_Ekoturizm_Kaynaklarinin_Gelistirilmesi_Dogu_Marmara_Ornegi $(10.10 .2021)$.

Akgöz, E., Göral, R. ve Tengilimoğlu, E. (2016). Turistik Ürün Çeşitlendirmenin Sürdürebilir Destinasyonları Açısından Önemi, Akademik Bakış Uluslararası Hakemli Sosyal Bilimler EDergisi, Sayı 55 Mayıs Haziran, 397-407. Erişim adresi: http://dergipark.gov.tr/download/articlefile/383356 (14.10.2021).

Akyurt, H. (2019). Ekoturizm: Türkiye'deki Gelişimi ve Mevcut Durumu, Sosyal, Beşerî ve İdari Bilimler Alanında Araştırma ve Değerlendirmeler, Haziran- Cilt 2, 355-367. Erişim Adresi:Https://Www.Researchgate.Net/Publication/335756678_Ekoturım_Turk1ye\%27dek1_Ge 11s1m1_Ve_Mevcut_Durumu (21.09.2021).

Arat, T. Ve Çalımlı, Y. (2018). Turizm Endüstrisinde Sürdürülebilir Kalkınma İçin Eko Turizmin Önemi: Konya’da Bir Araştırma, Çatalhöyük Uluslararası Turizm ve Sosyal Araştırmalar Dergisi, Sayl 3,23-39. Erişim adresi: http://sutsad.selcuk.edu.tr/index.php/sutsad/article/view/201 (21.09.2021).

Ardıç Yetiş, Ş. ve Çokal Z. (2018). Kış Turizmi Alanda Yayımlanan Makalelerin Bibliyometrik Profili, Journal Of Recreation And Tourism Research, 5(1),38-52. Erişim Adresi: (Pdf) Kıș Turizmi Alanında Yayımlanan Makalelerin Bibliyometrik Profili (Researchgate.Net) (12.10.2021).

Aslan, E. V. ve Güneş, S. G. (2015). Sürdürebilir Turizm ve Konaklama İşletmeleri için Yeşil Anahtar Eko-Etiketi, Uluslararası Türk Dünyası Turizm Sempozyumu, Sayı (1),608-617. Erişim adresi: (PDF) Sürdürülebilir Turizm ve Konaklama İşletmeleri için Yeşil Anahtar Eko-Etiketi Engin Aslan - Academia.edu (23.10.2021).

Aydın Tükeltürk, Ş. ve Boz, M. (2013). Turizmde Güncel Konu ve Eğilimler, Detay Yayıncılık, Ankara.

Aytuğ, K. (2016). Avrupa Birliği Turizm ve Çevre Politikaları Bağlamında Doğu Karadeniz Yeşil Yol, Karadeniz Araştırmaları Merkezi, 13(52),159-170. Erişim adresi: 
https://www.researchgate.net/publication/311854859_Avrupa_Birligi_Turizm_ve_Cevre_Politik alari_Baglaminda_Dogu_Karadeniz_Yesil_Yol (29.10.2021).

Başer, F. ve Başçı, A. (2012). İnanç Turizmi Kapsamında Aziz Pavlus Evinin Önemi ve Tanıtım Faaliyetlerine İlişkin Ziyaretçi Görüşlerinin Değerlendirilmesi, Mustafa Kemal Üniversitesi Sosyal Bilimler Enstitüsü Dergisi, 9(19),423-443. Erişim adresi: İnanç Turizmi Kapsamında Aziz Pavlus Evinin Önemi Ve Tanıtım Faaliyetlerine Illişkin Ziyaretçi Görüșlerinin Değerlendirilmesi - Pdf Free Download (Docplayer.Biz.Tr) (07.10.2021).

Baykal, D. ve Çimen, H. (2015). Sürdürülebilir Turizm ve Ekoturizm Sertifikaları, Doğu Karadeniz Sürdürebilir Turizm Kongresi,15-16 Mayıs, ss.10-21, Gümüşhane.

Buluç, G. (1997). Turistik Çekicilik Kaynaklarının Planlamasında Turistik Ürün Çeşitlendirmesi, H. Ü. İktisadi ve İdari Bilimler Fakültesi Dergisi, 15(2),140-160. Erişim adresi: Hacettepe Üniversitesi İktisadi ve İdari Bilimler Fakültesi Dergisi » Makale » Turistik Çekicilik Kaynaklarının Planlanmasında Turistik Ürün Çeşitlendirmesi (dergipark.org.tr) (21.10.2021).

Butler, Stephen ve BOYD, Richard; (1996), "Seeing the Forest Through the Trees: Using GIS to Identify Potential Ecotourism Sites in Northern Ontario." iç. L.C. Harrison and W. Husbands (Eds). PracticingResponsibleTourism: International case studies in tourism planning, policy and development. John Wiley and Sons, New York, 380-403.

Demir, M. ve Şen Demir, Ş. (2004). Turistik Ürün Çeşitlendirme Kapsamında Futbol Turizmi: Antalya Bölgesinde Bir Araştırma, Dokuz Eylül Üniversitesi Sosyal Bilimler Enstitüsü Dergisi, 6(1),94-116.

Dinçer Şen, S. (2010). Turizmin Çevresel Etkileri ve Bir Çözüm Olarak Ekoturizm, Yüksek Lisans Tezi, Mersin Üniversitesi, Sosyal Bilimler Enstitüsü, Kamu Yönetimi Ana Bilim Dalı, Mersin. Erişim adresi: Ulusal Tez Merkezi 1 Anasayfa (yok.gov.tr) (23.10.2021).

Doruk, T. T. (2019). Bir Sağlık Turizm Örneği Olarak Termal Turizm: Türk Sağlık Turizmi İçindeki Yerinin Çeşitli Boyutlarıyla İncelenmesi, Yüksek Lisans Tezi, İstanbul Üniversitesi Sosyal Bilimler Enstitüsü, Turizm İşletmeciliği Anabilim Dalı, İstanbul. Erişim adresi: sağlık Turizmi ve Türkiye'de Sağlık Turizminin Mevcut Durumu (istanbul.edu.tr) (16.10.2021). 
Fang-Chi K. ve Cheng-Ter K. (2012). Integrated bed and breakfast into ecotourism in Guan Ziling areas in Taiwan. Procedia- Social and Behavioral Sciences, 57(2012), 503- 510. doi: https://doi.org/10.1016/i.sbspro.2012.09.1217

Gök, H.N ve Özkoç A.Z. (2020). Kapadokya Bölgesinde Yerel Paydaşların Ekoturizme Yönelik Görüşleri, USBAD Uluslararası Sosyal Bilimler Akademi Dergisi, Sayı.4 Issue.4. doi : https://doi.org/10.47994/usbad.824367

Gökçe, F., Gökçe, H. ve Kocabozdoğan, K. (2015). Yayla Turizminin Sürdürebilirliği Kapsamında Çevresel Etki Boyutu: Kazıkbeli Yaylası Örneği, Doğu Karadeniz Bölgesi Sürdürebilir Turizm Kongresi,14-16 May1s 2015, ss. 689-701, Gümüşhane.

Güngör Özkök, F. ve Çoban, Ö. (2009) Ekoturizm mi Ekoterörizm mi, Detay Yayınc1lık, Ankara. Güzel, F.Ö. (2010). Turistik Ürün Çeşitlendirme Kapsamında Yeni Bir Dinamik: İnanç Turizm, Süleyman Demirel Üniversitesi Vizyoner Dergisi 2(2): 87-100. Erişim adresi: https://dergipark.org.tr/tr/pub/vizyoner/issue/23022/246163

Herbig P. ve O'hara B. (1997). Ecotourism: a Guide for Marketers, Europen Business Review, 97 (5), 231-236. doi: 10.1108/09555349710179843

Honey, Martha. (2007). The Role of Certification and Accreditation in Ensuring Tourism Contributes to Conservation. In Bushell, R. ve P. Eagles. (Eds.). Tourism and Protected Areas: Benefits beyond Boundaries. London: CABI Publishing, 168-190.

İstanbullu Dinçer, F., Ofluoğlu, M. ve Öz, M. (2015). Sürdürebilirlik Kapsamında Sakin Kent Felsefesi ve Yönetsel Sorunlar; Halfeti, Doğu Karadeniz Bölgesi Sürdürebilir Turizm Kongresi,14-16 Mayıs 2015, 325-336, Gümüşhane.

Juric, B., Cornwell, T. B. ve Mather, D. (2002). Exploring the Usefulness of an Ecotourism Interest Scale, Journal of Travel Research, 40 (3),259-269. doi: 10.1177/0047287502040003004

Kasalak, M. A. ve Akıncı, Z. (2015). Ekoturizmin Yerel Halk Üzerindeki Etkilerinin Değerlendirilmesi, Internetional Journal of ocial Sciences and Education Research, 1(1),231-239. doi: https://doi.org/10.24289/ijsser.106408 
Kasalak, M.A. (2014). Ekoturizm Girişimcilerinin İnovasyona Yatkınlığının Ölçülmesi: Muğla Yöresinde Yer Alan Ekolojik Oteller Kapsamında Bir Alan Araştırması, Doktora Tezi, Selçuk Üniversitesi, Sosyal Bilimler Enstitüsü, İşletme Anabilim Dalı, Konya.

Kasalak, M.A. ve Bahtiyar, D. (2017). Ege ve Akdeniz Bölgelerini Seyahat Eden Ekoturistlerin Sosyo-Demografik Özellikleri ve Motivasyonları Üzerine Bir Araştırma, Uluslararası Sosyal Araştırmalar Dergisi, 10(52),1089-1096. Erişim adresi: (Pdf) Ege Ve Akdeniz Bölgelerini Seyahat Eden Ekoturistlerin Sosyo-Demografik Özellikleri Ve Motivasyonları Üzerine Bir Araştırma (Ecotourısts Traveling In Aegean And Mediterranean Regions On Sociodemographic Characterıstıcs And Motıvatıons Research)- Murad Alpaslan Kasalak, Dilara Bahtiyar 1 Dilara Bahtiyar Sarı - Academia.edu (12.11.2021)

Kıral, B. (2020). Nitel Bir Veri Analizi Yönetimi Olarak Doküman Analizi, Sosyal Bilimler Enstitüsü Dergisi, Sayı:15,170-189. Erişim adresi: siirt Üniversitesi Sosyal Bilimler Enstitüsü Dergisi » Makale » Nitel Bir Veri Analizi Yöntemi Olarak Doküman Analizi (dergipark.org.tr)

Kızılırmak, İ., Kaya, F., Yıldız, S. ve Kurtulay, Z. (2017). Yerel Paydaşların Ekoturizme Yönelik Yaklaşımları: Erzincan Destinasyon Örneği, Erzincan Üniversitesi Sosyal Bilimler Enstitüsü Dergisi, 189-202. Erişim adresi: 341026 (dergipark.org.tr) (23.10.2021).

Korkmaz, H. ve Yavaş, B. (2020). Çanakkale İli Eceabat İlçesinin Ekoturizm Potansiyelinin Değerlendirilmesi, Journal of Global Tourism and Technology Research, 1(1):12-33. Erişim adresi: chromeextension://efaidnbmnnnibpcajpcglclefindmkaj/viewer.html?pdfurl=https $\% 3 \mathrm{~A} \% 2 \mathrm{~F} \% 2 \mathrm{Fdergipar}$ k.org.tr\%2Ftr\%2Fdownload\%2Farticle-file\%2F1554650\&chunk=true (18.11.2021).

Kozak, M. ve Bigne, E.; "Gonzalez, A. ve Andreu, L. (2003). Cross-Cultural Behavior Research In Tourism: A Case Study On Destination Image". Tourism Analysis. 8 (2): 44-58. (18.11.2021).

Kurnaz, A. ve Babür, T.E. (2018). Flora-Fauna ve Endemik Türlerin Ekoturizm Ürünü Olarak Kullanılması: Datça Yöresi Örneği, Mesleki Bilimler Dergisi, 7(2):410-419. Erişim adresi: https://dergipark.org.tr/tr/pub/mbd/issue/40281/443237 (22.10.2021).

Kurtoğlu, R. ve Temiz, S. (2018). Destinasyon Pazarlaması Kapsamında Ekoturizm Destinasyonu Olarak Kapadokya Bölgesi’nin Potansiyelinin Yerli Turistler Tarafindan Değerlendirilmesi, Gümüşhane Üniversitesi Sosyal Bilimler Dergisi, 9(22):90-108. 
Kutluay Tutar, F. (2015). Yeşil Ekonomi, Yeşil Turizm: Sektöründe Yeni Trend Yeşillenen Oteller Projesi, Akademik Sosyal Araştırmalar Dergisi, 3(13),328-352. Erişim adresi: https://asosjournal.com/?mod=tammetin\&makaleadi=\&makaleurl=307451148_679\%20Filiz\%20 Kutluay\%20Tutar.pdf\&key=33223 (29.11.2021).

Nalınçak, S. (2020). Sürdürebilir Ekoturizm: Her Zaman Mümkün mü, İzmir Kâtip Çelebi Üniversitesi Fen Bilimler Enstitüsü, Yüksek Lisans Tezi, İzmir.

Ongun, U., Yeşiltaş, M., Sop, S.A. ve Akıncı Ekiztepe, B. (2017). Alternatif Bir Ekoturizm Merkezinin İncelenmesi: Lisinia Doğa Örneği, Akademik Araştırmalar ve Çalışmalar Dergisi, 9(16): 49-60. doi: 10.20990/kilisiibfakademik.288245 (13.11.2021).

Polat, A.T. (2006). Karapınar İlçesi ve Yakın Çevresi Peyzaj Özelliklerinin Ekoturizm Kullanımları Yönünden Değerlendirilmesi Üzerine Bir Araştırma, Selçuk Üniversitesi Fen Bilimleri Enstitüsü, Doktora Tezi, Konya.

Ross, S., Wall, G. (1999). Ecotourism: Towards Congruence Between Theory And Practice. Tourism Management, 20 (1), 123-132. Erişim adresi: Pll: S0261-5177(98)00098-3 (widecast.org) (15.10.2021).

Satar, İ. (2016). Türkiye'de Sürdürebilir Turizm Açısından Sertifikasyon: Yeşil Yııldız ve Yeşil Anahtar Uygulamaları, Yüksek Lisans Tezi, Ankara Üniversitesi, Sosyal Bilimler Enstitüsü, Sosyal Çevre Bilimleri Anabilim Dalı, Ankara.

Scheyvans, Regina. (1999). Ecotourism and The Empowerment of Local Communities, Tourism Management, 20 (2) :245-249 doi: https://doi.org/10.1016/S0261-5177(98)00069-7

Şahin, İ. ve Kutlu, S. Z. (2014). Cittaslow: Sürdürülebilir Kalkınma Ekseninde Bir Değerlendirme, Journal of Tourism and Gastronomy Studies 2(1), 55-63. Erişim adresi: 2014 vol2 issue1 article7.pdf (jotags.org) (28.10.2021).

Şekerli, S. (2018). Tarım Turizmi (TaTuTa) Projesi Kapsamında Faaliyet Gösteren Ekolojik Çiftliklerde Bir Araştırma İzmir İli Örneği, Yüksek Lisans Tezi, İzmir Kâtip Çelebi Üniversitesi, Sosyal Bilimler Enstitüsü, Turizm İşletmeciliği Anabilim Dalı, İzmir. 
Tekin, Ö. (2014). Turistik Ürün Çeşitlendirmesi Kapsamında Konya'da Ekoturizm Rotaları, Yüksek Lisans Tezi, Necmettin Erbakan Üniversitesi, Sosyal Bilimler Enstitüsü, Turizm İşletmeciliği Anabilim Dalı, Konya.

Temizkan, S.P., Çiçek, D. ve Özdemir, C. (2015). Sağlık Turizmi Konusunda Yayınlanan Makalelerin Bibliyometrik Profili, International Journal of Human Sciences 12(2):395-415.

Tetik, N. (2012). Turist Rehberlerinin Ekoturizm Alanındaki Yeterlilikleri: Doğu Karadeniz Örneği, Doktora Tezi, Balıkesir Üniversitesi, Sosyal Bilimler Enstitüsü, Turizm İşletmeciliği ve Otelcilik Anabilim Dalı, Balıkesir.

Turpcu, E. ve Çelikkanat Paslı, N. (2019). Ekoturizmin Etkileri ve Destinasyon Aidiyeti Arasındaki İlişkinin Analizi: Giresun İli Örneği, Journal of Recreation and Tourism Research, $6(4), 412-424$.

Tutcu, A. (2021). Ekoturizm ve Türkiye'nin Ekoturizm Potansiyelinin Değerlendirilmesi, Atlas Ulusal Sosyal Bilimler Dergisi,5(6), 1-16. Erişim adresi: Atlas Sosyal Bilimler Dergisi " Makale » Ekoturizm Ve Türkiye'nin Ekoturizm Potansiyelinin Değerlendirmesi (dergipark.org.tr) (18.11.2021).

Uğurlu, K. ve Akay, B. (2017). Doğa Bilinçli Nesiller Yetiştirmede Ekoturizmin Önemi: Kırklareli İli-Dereköy Doğa Eğitim Merkezi Örneği, Erzincan Üniversitesi Sosyal Bilimler Enstitüsü Dergisi, 27-38. Erişim adresi: Erzincan Üniversitesi Sosyal Bilimler Enstitüsü Dergisi » Makale » Doğa Bilinçli Nesiller Yetiștirmede Ekoturizmin Önemi: Kırklareli Ili-Dereköy Doğa Eğitim Merkezi Örneği (Dergipark.Org.Tr) (14.11.2021)

Uysal, C. (2020). Sürdürebilirlik Kapsamında Ekoturizm ve Yerel Yönetimler: Samsun İli Örneği, Yüksek Lisans Tezi, Ondokuz Mayıs Üniversitesi, Lisansüstü Eğitim Enstitüsü, Kamu Yönetimi Anabilim Dal, Samsun.

Ünal Ankaya, F. ve Gülgün Aslan, B. (2019). Kent İçi Ulaşımda Bisiklet Yollarının Planlaması; Dünya ve Türkiye Örnekleri, Ulusal Çevre Bilimleri Araştırma Dergisi, Sayı 3(1),1-10. Erişim Adresi: Ecotourism in Turkey And The World: Social, Cultural And Economic Benefits (Dergipark.Org.Tr) (11.10.2021). 
Ünal Ankaya, F., Yazıcı, K., Balık, G. ve Gülgün Aslan, B. (2018). Dünyada ve Türkiye'de Ekoturizm, Sosyal-Kültürel ve Ekonomik Katkıları, Ulusal Çevre Bilimleri Araştırma Dergisi, Sayl 1(2), 69-72. Erişim adres: https://dergipark.org.tr/tr/download/article-file/512000 (22.11.2021).

Western, D. (1993). Defining ecotourism, Edited by Kreg Lindberg, Donald E. Hawkins, In Ecotourism: A Guide For Planners and Managers. North ennington: The Ecotourism Society, 8.

Yılmaz, H. (2008). Turizm Çeşitlendirmesi Kapsamında Ekoturizmin Ürünü Olarak Tatil Çiftlikleri: Türkiye'deki Tatil Çiftliklerine Yönelik Swot Analizi, Doktora Tezi, Afyon Kocatepe Üniversitesi, Sosyal Bilimler Enstitüsü, İşletmen Anabilim Dalı, Afyon. 